\title{
Knowledge, attitudes and sources of information on breastfeeding among medical professionals in Baghdad
}

H.H. Al-Nassaj, ${ }^{1}$ N.J.A. Al-Ward ${ }^{2}$ and N.A. Al-Awqati ${ }^{1}$

$$
\begin{aligned}
& \text { المعارف والمو اقف ومصادر المعلومات حول الروضاعة من الثدي لدى طلاب الطب والأطباء في بغداد }
\end{aligned}
$$

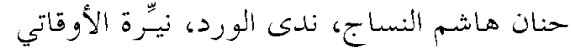

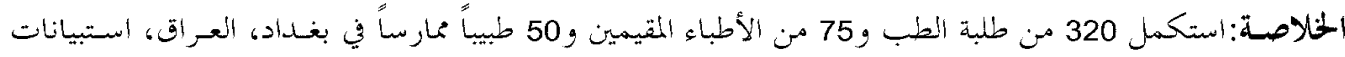

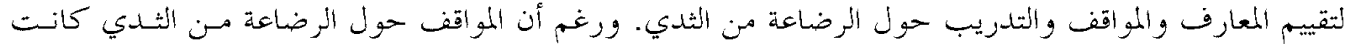

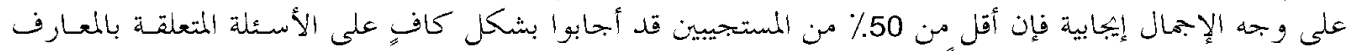

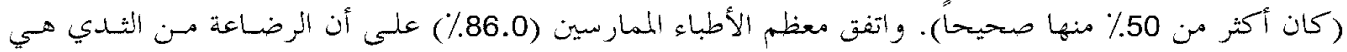

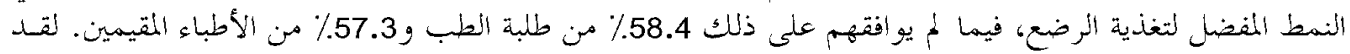

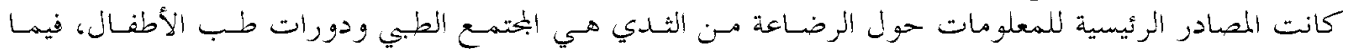

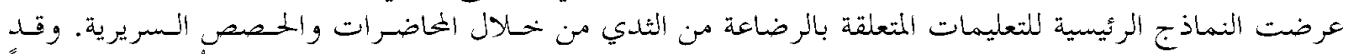

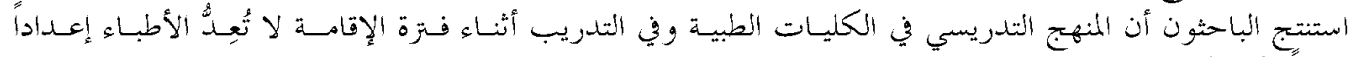

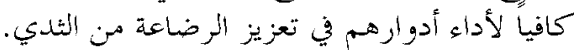

ABSTRACT A questionnaire to assess doctors' knowledge, attitudes and training about breastfeeding was answered by 320 medical students, 75 resident doctors and 50 general practitioners in Baghdad, Iraq. Although attitudes towards breastfeeding were generally positive, less than $50 \%$ of medics had adequate scores on knowledge questions ( $\geq 50 \%$ correct). Most general practitioners $(86.0 \%)$ agreed that breastfeeding was the preferred type of feeding compared with only $58.4 \%$ of medical students and $57.3 \%$ of resident doctors. General practitioners who had been on training courses scored better than those who had not. The main sources of breastfeeding information were community medicine and paediatric courses and the main modes of breastfeeding instruction were lectures and clinical sessions. Medical school curricula and residency training do not adequately prepare physicians for their role in breastfeeding promotion.

\begin{abstract}
Connaissances, attitudes et sources d'information concernant l'allaitement au sein chez les étudiants en médecine et les médecins à Bagdad

RÉSUMÉ Trois cent vingt (320) étudiants en médecine, 75 internes et 50 généralistes à Bagdad (Iraq) ont répondu à un questionnaire visant à évaluer les connaissances, les attitudes et la formation des médecins concernant l'allaitement au sein. Même si les attitudes vis-à-vis de l'allaitement au sein étaient généralement positives, moins de $50 \%$ des médecins ont eu un score satisfaisant pour les questions relatives aux connaissances $(\geq 50 \%$ de réponses correctes). La plupart des généralistes $(86,0 \%)$ reconnaissaient que l'allaitement au sein était le type d'alimentation préféré contre seulement $58,4 \%$ des étudiants en médecine et $57,3 \%$ des internes. Les généralistes qui avaient bénéficié d'une formation ont eu un meilleur score que ceux qui n'en avaient pas bénéficié. Les principales sources d'information sur l'allaitement au sein étaient les cours de médecine communautaire et de pédiatrie et les principaux modes d'instruction étaient les cours magistraux et les sessions cliniques. Le programme d'études des écoles de médecine et la formation des internes ne préparent pas suffisamment les médecins au rôle qu'ils ont à jouer dans la promotion de l'allaitement au sein.
\end{abstract}

'Maternal and Child Health Section, Ministry of Health, Baghdad, Iraq.

${ }^{2}$ Department of Community Medicine, College of Medicine, University of Baghdad, Baghdad, Iraq.

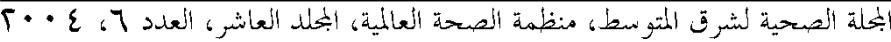




\section{Introduction}

It has been estimated that the lives of 1 million infants a year can be saved in the developing world by promoting breastfeeding [1]. In addition to the nutritional and psychological values of breast milk, it contains antibodies that help to protect the baby against many common childhood diseases. It is clean, always at the right temperature, inexpensive and nearly every mother has more than enough of this high quality food for her baby. For such a promotional campaign to be effective, attitudes and practices of health providers must be changed [1-3]. Health professionals need accurate, current scientific information combined with lactation and breastfeeding management skills [4-7]. In order to assure the availability of such professionals, clinical learning opportunities concerning lactation and breastfeeding must become a core unit of medical and nursing education and of postgraduate training in prenatal specialties [8-13].

It is now an established fact that breastfeeding is not a purely instinctive behaviour but it is an art transmitted from generation to generation and traditionally the skills of breastfeeding were handed down within families. Female relatives well-versed in the art of breastfeeding cared for new mothers and babies in the early weeks after childbirth. Breastfeeding has been undermined by the medicalization of pregnancy and childbirth and by commercial formula-milk popular since the 1950 s. In the past 50 years, mothers have given birth increasingly in hospitals, away from the help of their families and cared for by hospital personnel with at best little or no experience in breastfeeding instruction and at worst incorrect knowledge and prejudicial attitudes. Even more recently, mothers and babies are sent home from the hospital just 1 or 2 days af- ter delivery, long before the mother's milk has "come in" [14].

It was in this context that the present study was undertaken in Baghdad, Iraq to assess medical students' and physicians' knowledge, attitudes and training in relation to breastfeeding promotion. To the best of our knowledge, there are no pervious published studies on this subject in Iraq.

\section{Methods}

The study was carried out between 1 April and 31 July 2000. Three groups of health professionals completed questionnaires:

- Medical students from the 4th, 5th and 6th years at University of Baghdad, Saddam University and Al-Mustansirya University. Questionnaire forms were distributed randomly to 400 medical students in the classroom following lectures.

- Resident doctors from 6 different hospitals selected randomly from Baghdad governorate. With the aid of chief residents of the hospitals, questionnaire forms were distributed randomly to 100 resident doctors.

- General practitioners from 6 different primary health care centres selected randomly from Baghdad governorate. Questionnaire forms were distributed randomly to 75 general practitioners in their primary health care centres.

The self-administered questionnaires included questions to assess basic breastfeeding knowledge, attitudes and training experiences. The form was designed and reviewed by a panel of doctors including a breastfeeding consultant and was pretested on a random sample of 10 medical students and 5 resident doctors to check for clarity of interpretation and ease of completion. 
The questionnaire contained 50 items: 30 on knowledge about breastfeeding, 10 on problem-solving techniques, 6 on attitudes to breastfeeding and 4 on training about breastfeeding techniques. Regarding questions related to attitudes and teaching methods, participants were asked to choose the most accurate answer (some were multiple choice and other were yes/no format). For questions about breastfeeding knowledge and training experiences, participants given a series of statements and asked to score $\mathrm{T}$ for a true statement, $\mathrm{F}$ for a false one and D for don't know. Questions about problem-solving asked about suitable advice to give lactating mothers and suitable management of certain breastfeeding problems.

The pass mark for knowledge and problem-solving questions was $50 \%$ or more answers correct. To obtain a mean overall score for positive attitude, the percentages scoring positive for each question were summed and divided by 5 .

\section{Results}

The total number of respondents was 445 (265 males and 180 females). The response rates were $80.0 \%(320 / 400)$ for medical students, $75.0 \%$ (75/100) for resident doctors and $66.7 \%(50 / 75)$ for general practitioners.
Table 1 shows that general practitioners had the most positive attitudes towards breastfeeding when asked "What do you prefer for feeding your baby in the futuer?"; $86.0 \%$ thought breastfeeding was the preferred type of infant feeding compared with only $58.4 \%$ of medical students and $57.3 \%$ of resident doctors. Similarly, responses to all 5 attitude questions showed that more general practitioners had positive attitudes towards breastfeeding (Table 2).

In contrast with the low scores for preferred type of feeding, a high percentage of all respondents said that they encourage their family members and friends to breastfeed their babies (Table 2). Less than half of the medical students and residents (36.3\% and $49.3 \%$ ) agreed they would encourage a working mother to breastfeed her baby in her workplace compared with $60.0 \%$ of general practitioners. Only $38.7 \%$ of resident doctors and $40.9 \%$ of medical students thought it was appropriate for a mother to breastfeed her baby with modesty anywhere compared with $54.0 \%$ of general practitioners. A high proportion of all types of medic agreed that it is important to begin breastfeeding immediately after delivery. The mean percentage of general practitioners with positive attitudes was $76.8 \%$ compared with $68.8 \%$ for medical students and $70.1 \%$ for resident doctors.

\begin{tabular}{lccccccc}
\hline Table 1 Respondents' preferences for type of infant feeding \\
\hline $\begin{array}{l}\text { Type of feeding } \\
\text { preferred }\end{array}$ & $\begin{array}{c}\text { Medical students } \\
(\boldsymbol{n}=\mathbf{3 2 0})\end{array}$ & $\begin{array}{c}\text { Resident doctors } \\
(\boldsymbol{n}=\mathbf{7 5 )}\end{array}$ & $\begin{array}{c}\text { General practitioners } \\
(\boldsymbol{n}=\mathbf{5 0})\end{array}$ \\
\hline Bo. & $\%$ & No. & $\%$ & No. & $\%$ \\
\hline Artificial feeding or mixed feeding & 187 & 58.4 & 43 & 57.3 & 43 & 86.0 \\
\hline
\end{tabular}

$\mathrm{n}=$ number of respondents.

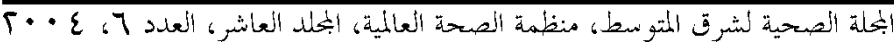




\begin{tabular}{|c|c|c|c|c|c|c|}
\hline \multirow[t]{2}{*}{ Attitude question } & \multicolumn{2}{|c|}{$\begin{array}{l}\text { Medical } \\
\text { students } \\
(n=320)\end{array}$} & \multicolumn{2}{|c|}{$\begin{array}{c}\text { Resident } \\
\text { doctors } \\
(n=75)\end{array}$} & \multicolumn{2}{|c|}{$\begin{array}{c}\text { General } \\
\text { practitioners } \\
(n=50)\end{array}$} \\
\hline & No. & $\%$ & No. & $\%$ & No. & $\%$ \\
\hline $\begin{array}{l}\text { Do you encourage your family } \\
\text { members and friends to } \\
\text { breastfeed their babies? }\end{array}$ & 314 & 98.1 & 73 & 97.3 & 50 & 100.0 \\
\hline $\begin{array}{l}\text { Do you encourage a working } \\
\text { mother to breastfeed her } \\
\text { baby in her workplace? }\end{array}$ & 116 & 36.3 & 37 & 49.3 & 30 & 60.0 \\
\hline $\begin{array}{l}\text { Do you think it is appropriate for } \\
\text { a mother to breastfeed her } \\
\text { baby with modesty anywhere? }\end{array}$ & 131 & 40.9 & 29 & 38.7 & 27 & 54.0 \\
\hline $\begin{array}{l}\text { Is it important to begin breastfeeding } \\
\text { straight after delivery? }\end{array}$ & 315 & 98.4 & 73 & 97.3 & 50 & 100.0 \\
\hline $\begin{array}{l}\text { Is it correct to ban the use of bottles } \\
\text { and teats in teaching hospitals } \\
\text { unless prescribed by doctors? }\end{array}$ & 224 & 70.0 & 51 & 68.0 & 35 & 70.0 \\
\hline Positive attitude (mean of 5 questions) & & 68.8 & & 70.1 & & 76.8 \\
\hline
\end{tabular}

Values are the number and percentage of respondents giving a positive response to each question.

$\mathrm{n}=$ number of respondents.

Table 3 shows that scores on knowledge and problem-solving approaches towards breastfeeding were slightly higher among general practitioners; $50.0 \%$ had adequate knowledge $\geq 50 \%$ of questions correct) compared with $45.3 \%$ of resident doctors and $49.1 \%, 47.5 \%$ and $40.0 \%$ of 6 th year, 5th year and 4th year medical students respectively. Of the 24 general practitioners who had received training, 75.0\% scored over the pass mark on the knowledge questions whereas of the 26 untrained general practitioners, $27.0 \%$ scored a pass. The training, which is only available for general practitioners, is a World Health Organization 40-hour course about breastfeeding counselling. It is not a standard course for all general practitioners but any may choose to take it.
The sources of information and modes of instruction about breastfeeding for medical students and resident doctors during their college years are shown in Table 4. Community medicine and paediatric courses were the most common sources of information while the obstetric course was the least frequent source. Lectures and clinical sessions were the most common modes of instruction about breastfeeding while video presentations were the least frequent mode.

\section{Discussion}

There were some limitations to the study design; the difficulty in convincing the doctors to participate in the study is reflected 


\begin{tabular}{|c|c|c|c|c|c|c|c|c|c|c|}
\hline \multicolumn{11}{|c|}{ Eastern Mediterranean Health Journal, Vol. 10, No. 6, 2004} \\
\hline \multicolumn{11}{|c|}{$\begin{array}{l}\text { Table } 3 \text { Respondents with adequate scores on knowledge about breastfeeding and problem- } \\
\text { solving approaches towards breastfeeding }\end{array}$} \\
\hline \multirow[t]{2}{*}{$\begin{array}{l}\text { Type of question } \\
\text { (no. of questions) }\end{array}$} & \multicolumn{2}{|c|}{$\begin{array}{c}\text { Medical } \\
\text { students } \\
\text { (4th year) } \\
(n=80)\end{array}$} & \multicolumn{2}{|c|}{$\begin{array}{l}\text { Medical } \\
\text { students } \\
\text { (5th year) } \\
(n=120)\end{array}$} & \multicolumn{2}{|c|}{$\begin{array}{l}\text { Medical } \\
\text { students } \\
\text { (6th year) } \\
(n=120)\end{array}$} & \multicolumn{2}{|c|}{$\begin{array}{c}\text { Resident } \\
\text { doctors } \\
(n=75)\end{array}$} & \multicolumn{2}{|c|}{$\begin{array}{c}\begin{array}{c}\text { General } \\
\text { practitioners }\end{array} \\
(n=50)\end{array}$} \\
\hline & No. & $\%$ & No. & $\%$ & No. & $\%$ & No. & $\%$ & No. & $\%$ \\
\hline $\begin{array}{l}\text { Knowledge } \\
\text { questions (30) }\end{array}$ & 36 & 45.0 & 54 & 45.0 & 66 & 55.0 & 47 & 62.7 & 25 & 50.0 \\
\hline $\begin{array}{l}\text { Problem-solving } \\
\text { questions (10) }\end{array}$ & 32 & 40.0 & 31 & 25.8 & 47 & 39.2 & 42 & 56.0 & 35 & 70.0 \\
\hline Total (40) & 32 & 40.0 & 57 & 47.5 & 59 & 49.1 & 34 & 45.3 & 25 & 50.0 \\
\hline
\end{tabular}

Values are the number and percentage of respondents scoring correctly on $\geq 50 \%$ of questions. $\mathrm{n}=$ number of respondents.

in the low response rate from general practitioners.

General practitioners had the most positive attitudes towards breastfeeding of the 3 groups of medics, with $86.0 \%$ agreeing that breastfeeding was the preferred meth- od of infant feeding and $76.8 \%$ having an overall positive attitude on 5 questions. This might be due to experience of breastfeeding for their own children and the fact that many had attended breastfeeding training courses. The teaching curriculum of

\begin{tabular}{|c|c|c|c|c|c|c|c|c|}
\hline \multirow[t]{2}{*}{$\begin{array}{l}\text { Sources of information/ } \\
\text { instruction }\end{array}$} & \multicolumn{2}{|c|}{$\begin{array}{c}\text { Medical } \\
\text { students } \\
\text { (4th year) } \\
(n=80)\end{array}$} & \multicolumn{2}{|c|}{$\begin{array}{c}\text { Medical } \\
\text { students } \\
(5 \text { th year) } \\
(n=120)\end{array}$} & \multicolumn{2}{|c|}{$\begin{array}{c}\text { Medical } \\
\text { students } \\
(6 \text { th year) } \\
(n=120)\end{array}$} & \multicolumn{2}{|c|}{$\begin{array}{c}\begin{array}{c}\text { Resident } \\
\text { doctors }\end{array} \\
\quad(n=75)\end{array}$} \\
\hline & No. & $\%$ & No. & $\%$ & No. & $\%$ & No. & $\%$ \\
\hline \multicolumn{9}{|l|}{ Sources of information } \\
\hline Community medicine & 61 & 76.3 & 89 & 74.2 & 58 & 48.3 & 34 & 45.3 \\
\hline Paediatrics & 36 & 45.0 & 114 & 95.0 & 104 & 86.7 & 75 & 100.0 \\
\hline Obstetrics & 0 & 0 & 8 & 6.7 & 12 & 10.0 & 16 & 21.3 \\
\hline Other $^{\mathrm{a}}$ & 0 & 0 & 2 & 1.7 & 3 & 2.5 & 0 & 0 \\
\hline \multicolumn{9}{|l|}{ Modes of instruction } \\
\hline Lectures & 80 & 100.0 & 120 & 100.0 & 120 & 100.0 & 75 & 100.0 \\
\hline Clinical sessions & 48 & 60.0 & 80 & 66.7 & 74 & 61.7 & 47 & 62.7 \\
\hline Breastfeeding & & & & & & & & \\
\hline demonstration & 19 & 23.8 & 20 & 16.7 & 28 & 23.3 & 28 & 37.3 \\
\hline Slides & 39 & 48.8 & 38 & 31.7 & 53 & 44.2 & 10 & 13.3 \\
\hline Videotape & 5 & 6.3 & 4 & 3.3 & 17 & 14.2 & 7 & 9.3 \\
\hline
\end{tabular}

asurgery.

$\mathrm{n}=$ number of respondents.

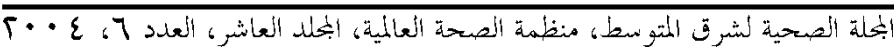


medical students in Iraqi universities includes little on infant feeding, rarely more than 2 hours of lectures, and residency training includes limited opportunities for direct patient interaction about breastfeeding [15].

It was found that a very high percentage of respondents would encourage breastfeeding among relatives and friends. These findings are higher than those of a study by Hollen on paediatricians and obstetricians in Los Angeles, California, which found that less than $45.0 \%$ of obstetricians and paediatricians would encourage an undecided mother to breastfeed [8]. Surprisingly, the proportion of medics preferring breastfeeding is lower than that encouraging breastfeeding among family members and friends. This discrepancy might be explained if most respondents know the benefits of breastfeeding so they encourage breastfeeding, but at the same time they believe that it is difficult for mothers to breastfeed their infants when they are working outside home most of the time. This reflects gaps in their knowledge about the practice of breastfeeding, milk expression and storage.

The present study also shows that a very high percentage of respondents thought that it was important to begin breastfeeding immediately after delivery. These results are higher than those found in a study done by Hull et al. in Indonesia, where they found that only $46.0 \%$ of 167 health professionals thought that breastfeeding should be initiated immediately after delivery [6].

Although obstetricians have the most important role on the decision to breastfeed and on the initiation of breastfeeding [16], the study shows that breastfeeding and infant feeding are generally dealt with during a course in paediatrics and community medicine. Rarely are these subjects dealt with during training in obstetrics and in other fields, and when they are, the instructions are usually essentially theoretical, while audio-visual materials, which can stimulate discussion or illustrate a specific aspect of the programme, are less frequently used [17-19]. These results are similar to that found by Freed et al. on paediatric and obstetric residents and practitioners from American medical colleges $[20,21]$.

The highest general positive attitude and success rates among general practitioners were probably due to the training courses that they had taken during their service life. This study found that $75.0 \%$ of general practitioners who were trained had adequate knowledge compared with only $27.0 \%$ who had not been trained, and this coincides with the results of Rea et al. on health professionals in Sao Paulo, Brazil [22].

\section{Conclusion}

Although attitudes toward breastfeeding were generally positive among medical students and physicians in Baghdad, there were many areas in which knowledge was incomplete and in which wide variation existed in advice given to breastfeeding mothers. Thus the need for improved training of doctors is clear. It is necessary, however, to learn more about what constitutes effective, high quality training, including content and methodology and necessary hours of teaching and of supervised clinical practice, instead of just the effect of "any" versus "no" training.

\section{Acknowledgement}

Great appreciation is due to all medical students and doctors for their cooperation in answering the study questionnaire. 


\section{References}

1. Naylor A. Professional education and training for trainers. International journal of gynaecology and obstetrics, 1990, 31(suppl. 1):25-7.

2. Hafez G, Baghchi K. Promoting breastfeeding through $\mathrm{MCH}$ services and primary health care. WHO Regional Office for the Eastern Mediterranean, Alexandria, Egypt, 1995:7-36 (unpublished document no. WHO-EMIMCHI239-E/G; available from Division of Health Protection and Promotion, WHO EMRO, Cairo).

3. Lawrence RA, ed. Breastfeeding: a guide for the medical profession, 4th ed. St Louis, Missouri, Mosby, 1994:118-48, 285-306, 912-20.

4. Anand BK. Recommendations on breastfeeding promotion among pediatricians. International journal of gynaecology and obstetrics, 1990, 31(suppl. 1):51-5.

5. Maheshwari BK et al. Knowledge and attitudes of rural health personnel regarding infant feeding. Indian journal of pediatrics, 1987, 54:930-4.

6. Hull VJ, Thapa S, Wiknjosastro G. Breastfeeding and health professionals: a study in hospitals in Indonesia. Social science and medicine, 1989, 28(4):35564.

7. Mundo FD, Gracia FD. Programmes to promote breastfeeding in the Philippines: recent developments. In: Jelliffe DB, Jelliffe EFP, eds. Programmes to promote breastfeeding. Oxford, Oxford University Press, 1988:127-32.

8. Freed OL. Breast-feeding. Time to teach what we preach. Journal of the American Medical Association, 1993, 269(2):2435.

9, Savage F, Daelmans B. Training health care workers to counsel breastfeeding mothers. Dialogue on diarrhoea, 1995, 59:2.
10. Jelliffe EFP. Breastfeeding modules for integration into the curriculum of health professionals. In: Jelliffe DB, Jelliffe EFP, eds. Programmes to promote breast feeding. Oxford, Oxford University Press, 1988:308-12.

11. Evidence for the ten steps to successful breastfeeding. Geneva, World Health Organization, 1998:14-8 (WHO/CHDI 98.9).

12. Breastfeeding promotion in practice: facts for action for health professionals. Cairo, World Health Organization/ UNICEF, 1993:3-15.

13. Harfouche JK, Musaiger AO, eds. Breastfeeding patterns: a review of studies in the Eastern Mediterranean Region, 2nd ed. Alexandria, World Health Organization, Regional Office for the Eastern Mediterranean, 1993:8-28 (EMRO Technical Publications series, No. 4).

14. Stashwick CA. When a breastfed infant isn't gaining weight. Contemporary pediatrics, 1993, 10(5):116-35.

15. Lactation management training. In: Saadeh RJ, ed. Breast-feeding: the technical basis and recommendations for action. Geneva, World Health Organization, 1993:49-59 (WHO/NUT/MCH/93.I).

16. Howard FM, Howard CR, Weitzman M. The physician as advertiser: the unintentional discouragement of breast-feeding. Obstetrics and gynecology, 1993, 81(6): 1048-51.

17. Bedinghaus JM, Melnikow J. Promoting successful breast feeding skills. American family physician, 1992, 45(3):130918.

18. Naylor AJ, Wester RA. Health professional education: a key to successful breastfeeding promotion programmes. In: Jelliffe DB, Jelliffe EFP, eds.

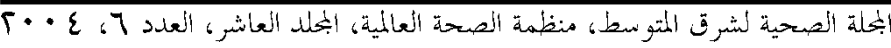


Programmes to promote breastfeeding. Oxford, Oxford University Press, 1988: 313-9.

19. Pechevis M. Training health personnel in the area of breast-feeding. Assignment children, 1981, 55/56:91-I05.

20. Freed $\mathrm{GL}$ et al. Pediatrician involvement in breast-feeding promotion: a national study of residents and practitioners. $\mathrm{Pe}$ diatrics, 1995, 96(3 Pt1):490-4.
21. Freed GL et al. Breastfeeding education of obstetrics-gynecology residents and practitioners. American journal of obstetrics and gynecology, 1995, 173(5): 1607-13.

22. Rea MF et al. Counselling on breastfeeding: assessing knowledge and skills. Bulletin of the World Health Organization, 1999, 77(6):492-8.

\section{Regional workshop on infant and young child feeding}

The World Health Organization organized a regional workshop on infant and young child feeding in Casablanca, Morocco, from 28 to 31 July 2003. The objectives of the workshop were to review the present status of infant and young child feeding in countries of the Eastern Mediterranean Region in relation to the global strategy for infant and young child feeding, and also to develop an outline of a country plan of action for promoting the implementation of the global strategy for infant and young child feeding at the national level in Member States. Experts from Afghanistan, Bahrain, Egypt, Islamic Republic of Iran, Morocco, Oman, Pakistan, Sudan, Syrian Arab Republic and Tunisia participated in the workshop as well as from UMICEF, FAO, USAID/West Bank, some nongovernmental organizations and WHO concerned staff. 